\title{
PENGARUH MEDIA TANAM TERHADAP RESPON PERTUMBUHAN DAN PRODUKSI GENOTIPE Moringa Oleifera $(\mathrm{L})$
}

\author{
Ida Ekawati $^{1)} *$, Henny Diana Wati ${ }^{2)}$ \\ Dosen Fakultas Pertanian Universitas Wiraraja \\ email : idaekawatee@yahoo.co.id dan hennydianawati@yahoo.co.id \\ * Penulis Koresponden: idaekawatee@yahoo.co.id
}

\begin{abstract}
ABSTRAK
Media tanam pada tanaman kelor (Moringa Oleifera) berperan penting terhadap keberlangsungan pertumbuhan tanaman dan akar. Tanaman kelor tumbuh baik di perkarangan tanpa adanya penambahan unsur hara terhadap media tanam. Tujuan penelitian adalah untuk mengetahui pengaruh media tanam terhadap respon pertumbuhan dan produksi daun kelor. Hasil macam perlakuan media tanam yang berpengaruh tidak nyata terhadap beberapa parameter yang diamati yaitu jumlah tunas dan panjang akar. Sementara yang menunjukkan pengaruh nyata dan sangat nyata adalah parameter tinggi tunas dari bibit asal stek batang pada tanaman kelor.

Kata kunci: Kelor (Moringa Oleifera), Media Tanam, dan Pertumbuhan

\section{PENDAHULUAN}

Tanaman kelor saat ini menjadi perhatian dunia, mengingat kandungan gizi tanaman ini cukup tinggi sehingga digunakan untuk mengatasi malnutrisi di banyak negara berkembang (Krisnadi, 2015). Dikatakan bahwa tanaman kelor merupakan tanaman yang paling bermanfaat di dunia (Amaglo, 2006). Daun kelor memiliki kandungan antioksidan relatif tinggi sehingga daun kelor menjadi bahan industri kosmetik, di antaranyaantioksidan daun kelor diekstrak untuk sediaan krim hand body (Hardiyanthy, 2015). Kandungan protein, vitamin $C$ maupun vitamin A sangat tinggi bahkan dapat mencapai dua kali lipat kandungan vitamin $\mathrm{C}$ jeruk dan dua kali kandungan vitamin A wortel (Krisnadi, 2015). Selain itu, kelor juga memiliki efek farmakologis sebagai antiinflamasi, anti piretik dan antiskorbut.

Mengingat tingginya nilai gizi tanaman ini, kelor yang sebelumnya hanya ditanam sebagai tanaman pagar, saat ini kelor banyak dibudidayakan untuk dijual daunnya atau dimanfaatkan bagian tanaman lainnya seperti biji kelor sebagai penjernih air (Foild et. al., 2001). Daun kelor juga diolah menjadi teh kelor maupun dibuat kapsulbubuk daun kelor, sehingga daun kelor mempunyai nilai ekonomi. Meningkatnya permintaan daun kelor untuk produksi olahan, maka diperlukan suatu penelitian tentang budidaya kelor yang baik agar diperoleh produksi yang tinggi dan berkualitas. Pertumbuhan tanaman kelor salah satunya dipengaruhi oleh media tanam. Media

tanam yang baik akan memberikan dukungan terhadap produksi kelor yang tinggi.

Umumnya kelor ditanam di lahan kering marginal yang memiliki keterbatasan dalam penyediaan unsur hara maupun air. Oleh karena itu diperlukan bahan pembenah tanah untuk mendukung pertumbuhan tanaman. Bahan pembenah yang dapat digunakan di antaranya arang sekam dan pupuk organik (Nugroho, 2013; Aurum, 2005). Penambahan pupuk organik pada media tanah dapat memperbaiki sifat fisik, kimia dan biologi tanah (Hakim, 1999). Kapasitas menahan air meningkat dengan penambahan pupuk organik dan tanah mineral pada media pasir (Nugroho, 2013). Hasil penelitian lain menunjukkan bahwa pemanfaatan arang sekam dapat meningkatkan pertumbuhan bibit Jabon (Supriyanto dan Fiona, 2010). Tanah dan pupuk kandang sangat bagusuntuk pertumbuhan tanaman jarak terutama pada awal pertumbuhan atau di pembibitan (Hariyadi, 2008).

Penelitian ini difokuskan pada pertumbuhan awal stek kelor, mengingat pertumbuhan awal merupakan modal dasar untuk pertumbuhan selanjutnya. Pemberian bahan pembenah tanah seperti arang sekam maupun pupuk organik diharapkan dapat mendukung pertumbuhan awal bibit yang lebih baik di pembibitan. Oleh karena itu, dari penelitian ini diharapkan diperoleh informasi campuran media arang sekam, pupuk organik, dan tanah terbaik untuk menghasilkan pertumbuhan dan produksi biomassa daun keloryang tinggi.
\end{abstract}


Penelitian ini bertujuan untuk mengetahui pengaruh media tanam campuran tanah, arang sekam, pupuk organik terhadap respon pertumbuhan dan produksi daun tanaman kelor (Moringa oleifera). Hasil penelitian ini nantinya dapat diaplikasikan pada media tanam di pembibitan baik menggunakan bahan tanam stek maupun biji serta dapat diaplikasikan di lapang pada saat mempersiapkan media tanam pada lubang tanam untuk transpanting kelor (Moringa Oleifera $(\mathrm{L})$

\section{METODE PENELITIAN}

Penelitian dilaksanakan di Rumah Kaca (green house) Fakultas Pertanian Universitas Wiraraja Sumenep pada ketinggian tempat < 500 diatas permukaan laut dengan jenis tanah komplek mediteranlitosol (coklat) dan untuk analisis pertumbuhan dilakukan di Laboratorium Fakultas Pertanian Universitas Wiraraja Sumenep.

Pemilihan pohon induk yang akan dijadikan sumber stek dipilih yang sehat dan seragam terutama untuk diameter batang. Persiapan media tanam yang akan digunakan dimasukkan ke dalam polibag ukuran $15 \times 25 \mathrm{~cm}$ yang telah disediakan. Polibag diisi media tanam sesuai dengan perlakuan, dan diinkubasi selama 1 minggu.

Setelah tanaman induk ditentukan, dipilih batang yang akan dijadikan stek dengan diameter batang 2-3 cm. Kemudian dipotong sepanjang $20-25 \mathrm{~cm}$. Stek ditanam dalam polibagyang telah terisi media tanam sesuai perlakuan. Perawatan dan penyiraman dilakukan setiap hari agar kelembaban media tanam terjaga.

Penelitian ini merupakan penelitian percobaan dengan menggunakan Rancangan Acak Kelompok(RAK)yang terdiri 7 (tujuh) perlakuan media tanam. Macam media tanam dalam percobaan ini meliputi perlakuan : media tanah (A0), tanah+arang sekam dengan perbandingan 2:1 (A1), Tanah+arang sekam dengan perbandingan 1:1 (A2), tanah+arang sekam perbandingan 2:1 (A3), tanah+ arang sekam + pupuk kandang dengan perbandingan 2:1:1 (A4), tanah + arang sekam + pupuk kandang perbandingan 1:1:1 (A5),tanah+pasir hitam dengan perbandingan 2:1 (A6). Masingmasing perlakuan diulang 5 kali.

\section{HASIL DAN PEMBAHASAN}

Hasil penelitian ini menunjukkan bahwa dari perlakuan macam media tanam secara umum berpengaruh nyata terhadap pertumbuhan bibit asal stek batang kelor pada umur 120 hari setelah tanam (HST). Macam perlakuan media tanam yang berpengaruh tidak nyata terhadap beberapa parameter yang diamati yaitu jumlah tunas dan panjang akar. Sementara yang menunjukkan pengaruh nyata dan sangat nyata adalah parameter tinggi tunas dari bibit asal stek batang pada tanaman kelor. Sedangkan macam perlakuan media tanam yang berpengaruh sangat nyata pada parameter berat kering tunas, root/shoot rasio dan berat kering akar disajikan pada Tabel 4.1.

Tabel. 4.1 Nilai F-Hitung perlakuan komposisi media tanam pada berbagai parameter

\begin{tabular}{lr}
\hline \multicolumn{1}{c}{ Parameter } & Nilai F-Hit \\
\hline Jumlah Tunas & $1,356^{\text {ns }}$ \\
Tinggi Tunas & $3,958^{*}$ \\
Panjang Akar & $1,805^{\text {ns }}$ \\
Berat Kering Tunas & $4,989^{* *}$ \\
Root/Shoot Rasio & $10,468^{* *}$ \\
Berat Kering Akar & $9,733^{* *}$ \\
\hline
\end{tabular}

\section{A. Jumlah Tunas}

Hasil analisa sidik ragam terhadap jumlah tunas tanaman kelor menunjukkan bahwa tidak terdapat perbedaan jumlah tunas yang nyata di antara perlakuan komponen media tanam. Hal ini disebabkan pembentukan tunas masih menggunakan cadangan makanan pada stek batang. Jumlah tunas sangat dipengaruhi oleh senyawa karbohidrat yang terdapat pada sel tanaman. Indriyani et.al (1999) menyatakan bahwa akumulasi dari hasil fotosintat 
yang tinggi dapat menyebabkan pembesaran dan differensiasi sel yang dinyatakan dengan pertambahan tinggi tanaman, jumlah tunas, jumlah daun dan diameter batang pada tanaman.

Berdasarkan dari rata-rata jumlah tunas perlakuan media tanah, arang sekam, pupuk kandang degan perbandingan 1:1:1 yang memiliki jumlah tunas tebanyak.

\section{B. Tinggi Tunas}

Hasil analisa sidik ragam terhadap tinggi tunas tanaman kelor menunjukkan bahwa perlakuan komposisi media tanam berbeda nyata. Tinggi tunas tertinggi dihasilkan oleh perlakuan media tanam dengan menggunakan arang sekam, pupuk kandang degan perbandingan 1:1:1.

Tabel. 4.2 Rata-rata Tinggi Tunas Kelor $(\mathrm{cm})$ akibat perlakuan komposisi media tanam pada berbagai perlakuan

\begin{tabular}{cc}
\hline Perlakuan & Rata-rata Tinggi Tunas Kelor $(\mathrm{cm})$ \\
\hline A0 & $5,0 \mathrm{a}$ \\
A1 & $14,7 \mathrm{ab}$ \\
A2 & $20,0 \mathrm{~b}$ \\
A3 & $19,0 \mathrm{~b}$ \\
A4 & $13,7 \mathrm{a}$ \\
A5 & $31,3 \mathrm{c}$ \\
A6 & $19,0 \mathrm{~b}$ \\
\hline
\end{tabular}

\section{Uji Duncan 5\%}

Setelah diuji Duncan dari rata-rata tinggi tunas kelor pada perlakuan A5 memiliki tingkat karakteristik yang berbeda nyata dengan perlakuan lainnya. Sehingga perlakuan yang terbaik yaitu pada perlakuan A5. Perlakuan A4 tidak berbeda nyata dengan A0 dan A1, namun berbeda nyata dengan perlakuan A2, A3, dan A6.

Kadar $\mathrm{N}$ tanah yang rendah pada media tanam sangat mempengaruhi terhadap pertumbuhan fase vegetatif, yang dicirikan oleh penambahan volume sel tanaman (misalnya pada tinggi dan panjang tanaman) dan juga organ tanaman lainnya, yaitu berupa daun dan cabang baru. Saat fase pertumbuhan, peran unsur $\mathrm{N}$ sangat penting, khususnya pada saat pembelahan sel yang termasuk bagian dari proses metabolisme bagi tanaman.

Pelakuan media tanam tanah, arang sekam, pupuk kandang degan perbandingan 1:1:1 yang memiliki tinggi tunas teinggi. Rinsinema (1983), terjadinya peningkatan tinggi tanaman meupakan suatu pencerminan dari pertumbuhan tanaman sehingga menyebabkan perpanjangan ruas-ruas tanaman akibat dari memanjangnya dan membesarnya sel-sel tanaman. Seiring dengan bertambahnya umur tanaman, maka pertumbuhan dari tanaman ditentukan oleh tersedianya unsur-unsur hara dalam tanah (media tanam).

\section{Panjang Akar}

Hasil dari analisa sidik ragam terhadap panjang akar tanaman kelor menunjukkan bahwa perlakuan komposisi media tanam yang digunakan tidak berpegaruh nyata. Sistem perakaran pada tanaman akan mendukung percepatan pertumbuhan dari sejak tahap awal pertumbuhan melalui kemampuannya mengeksrak ketersediaan air pada lapisan tanahdangkal palin atasyang mudah hilang karena adanya evaporasi tanaman (Johansen et al. 1997) serta kemampuan 
mengekstrak air dari lapisan tanah yang paling dalam yang mendukung kemampuan tanaman untuk eradaptasi (Kashiwagi et al, 2006).

Air merupakan komponen utama dalam kehidupan tanaman, sekitar 70-90\% berat segar tanaman berupa air yang merupakan media penunjang untuk belangsungnya reaksi biokima. Dalam tubuh tanaman air dapat masuk ke jaringan tanaman melalui proses difusi. Dimana dalam proses ini dipengaruhi oleh banyak faktor diantaranya adanya faktor Tabel.4.3 Rata-rata Berat Kering Tunas Kelor (gr) akibat perlakuan komposisi media tanam pada berbagai perlakuan lingkungan yang berperan dalam proses keseimbangan air yang ada pada sistem tanah, tanaman, dan udara.

\section{Berat Kering Tunas}

Hasil analisis sidik ragam terhadapberat kering tunas kelor menunjukkanbahwa perlakuan media tanamberpengaruh sangatnyata hal ini dapat ditunjukkan pada Tabel 4.1. Ratarata berat kering tunas tanaman kelor pada semua perlakuan disajikan pada tabel 4.3 sebagai berikut:

\begin{tabular}{cc} 
Perlakuan & Rata-rata Berat Kering Tunas Kelor (gr) \\
\hline A0 & $0,70 \mathrm{a}$ \\
A1 & $1,23 \mathrm{ab}$ \\
A2 & $2,26 \mathrm{~b}$ \\
A3 & $1,84 \mathrm{~b}$ \\
A4 & $1,22 \mathrm{ab}$ \\
A5 & $3,01 \mathrm{c}$ \\
A6 & $1,27 \mathrm{ab}$ \\
\hline
\end{tabular}

Uji Duncan 5\%

Setelah diuji lanjutan dengan uji Duncan dari rata-rata kering tunas kelor pada perlakuan A5 memiliki tingkat karakteristik yang berbeda nyata dengan perlakuan lainnya. Sehingga perlakuan yang terbaik yaitu pada perlakuan A5. Perlakuan A0 tidak berbeda nyata dengan A1, A4 dan A6, namun berbeda nyata dengan perlakuan $\mathrm{A} 2$ danA3.

Tabel. 4.4 Rata-rata Berat Akar Kelor (gr) akibat perlakuan komposisi media tanam pada berbagai perlakuan

Perlakuan Rata-rata Berat Basah Akar Kelor (gr)

\begin{tabular}{cc}
\hline Perlakuan & Rata-rata Berat Basah Akar Kelor (gr) \\
\hline A0 & $0,21 \mathrm{a}$ \\
A1 & $0,26 \mathrm{ab}$ \\
A2 & $0,43 \mathrm{c}$ \\
A3 & $0,39 \mathrm{c}$ \\
A4 & $0,30 \mathrm{~b}$ \\
A5 & $0,46 \mathrm{c}$ \\
A6 & $0,43 \mathrm{c}$ \\
\hline
\end{tabular}

Uji Duncan 5\%

Dari hasil lanjutan uji duncan menunjukkan perlakuan A2, A3, A5, dan

\section{E. Root/Shoot Rasio}

Hasil analisis sidik ragam terhadapberat akar tanaman kelor menunjukkanbahwa perlakuan media tanamberpengaruh sangatnyata hal ini dapat ditunjukkan pada tabel 4.1. Ratarata berat akar tanaman kelor pada semua perlakuan disajikan pada tabel 4.4 sebagai berikut :
A6 memiliki tingkat karakteristik yang berbeda nyata. Perlakuan A0 tidak berbeda 
nyata dengan A1 tetapi berbeda nyata pada perlakuan A4. Hal ini menunjukkan perlakuan A5 memiliki nilai rata-rata tertinggi sehingga menunjukkan perlakuan yang terbaik.

\section{F. Berat Kering Akar}

Hasil analisis sidik ragam terhadapberat kering akar tanaman kelor menunjukkanbahwa perlakuan media tanamberpengaruh sangatnyata hal ini dapat ditunjukkan pada tabel 4.1. Ratarata berat kering akar tanaman kelor pada semua perlakuan disajikan pada tabel 4.5 sebagai berikut :

Tabel. 4.5 Rata-rata Berat Kering Akar Kelor (gr) akibat perlakuan komposisi media tanam pada berbagai perlakuan

\begin{tabular}{cc}
\hline Perlakuan & Rata-rata Berat Kering Akar Kelor (gr) \\
\hline A0 & $0,14 \mathrm{a}$ \\
A1 & $0,39 \mathrm{ab}$ \\
A2 & $0,95 \mathrm{~b}$ \\
A3 & $0,70 \mathrm{bc}$ \\
A4 & $0,38 \mathrm{a}$ \\
A5 & $1,37 \mathrm{c}$ \\
A6 & $0,54 \mathrm{a}$ \\
\hline
\end{tabular}

Uji Duncan 5\%

Setelah diuji Duncan dari ratarata berat kering akar kelor pada perlakuan A5 memiliki tingkat karakteristik yang berbeda nyata dengan perlakuan lainnya. Sehingga perlakuan yang terbaik yaitu pada perlakuan A5. Perlakuan A4 tidak berbeda nyata dengan A0 dan A6, namun berbeda nyata dengan perlakuan A1, A2,dan A3.

Berdasarkan hasil pengamatan pada stek tanaman kelor yang mati, tidak ada satupun yang menunjukkan adanya tingkat serangan hama ataupun penyakit. Kematian stek pada tanaman kelor ini ditandai dengan adanya

\section{KESIMPULAN DAN SARAN}

\subsection{KESIMPULAN}

1. Media tanam berpengaruh nyata terhadap parameter yang diamati kecualiparameter jumlah tunas dan panjang akar pada tanaman kelor.

2. Media tanammenggunakan tanah + arang sekam + pupuk kandang dengan perbandingan 1:1:1 perlakuan A5 yang paling efektif dalam pertumbuhan bibit asal stek batang kelor. pengeringan pada tunas dan tidak terdapatnya primordia akar pada bagian basal stek, yang seharusnya terdapat inisiasi akar. Padahal stek kelor tersebut sudah muncul tunas yang seharusnya dapat bertahan hidup dengan mensintesis makanannya sendiri. Akan tetapi dengan tidak terdapatnya akar maka stek tersebut tidak dapat menyerap air dan makanan dari media tanam yang dibutuhkan oleh stek untuk proses fotosintesis. Hartmann dan Kester (1983) menyatakan dalam perbanyakan tanaman secara vegetatif melalui stek, maka pertumbuhan akar merupakan faktor awal yang sangat penting bagi pertumbuhannya.

\subsection{SARAN}

Perlu dilakukan penelitian lanjutan terkait umur bahan stek kelor yang digunakan untuk mempelajari pengaruhnya terhadap keberhasilan pertumbuhan stek tanaman kelor. Penelitian tentang teknik pembibitan khusus untuk stek tanaman kelor juga perlu dilakukan.

\section{DAFTAR PUSTAKA}

Amaglo, N. 2006. How to Produce Moringa Leaves Efficiently? Moringa et Autres 
Végétaux À Fort Potentiel Nutritionnel: Stratégies, Normes et Marchés Pour Un Meilleur Impact Surla Nutrition enAfrique.,Accra, Ghana, 16-18 novembre 2006: 16-18.

Dalimoenthe, S.L. 2016. Sekam Padi sebagai Media Pembibitan Stek Teh. Warta Teh dan Kina. Rubrik Ilmiah. Vol. 7(4) : 112-115. Pusat Penelitian Teh dan Kina. Gambung.

Ferry, Y. 2014. Menghitung Perkiraan Produksi Jarak Pagar. Infotek Jarak Pagar. Vol. 1 No. 5 Mei. Diakses pada tanggal 03 April 2016.

Foidl, N., Makkar, H. P. S., Becker, K., Foild, N., \& Km, S. 2001. the Potential of Moringa Oleifera for Agricultural and Industrial Uses. What Development Potential for Moringa Products?, 1-20.

Gasperz, V. 1994. Metode Perancangan Percobaan. CV. Armico. Bandung.

Hardiyanthi, F. 2015. Pemanfaatan Aktivitas Antioksidan Ekstrak Daun Kelor (Moringa oleifra) dalam Sediaan Hand and Body Cream. Skripsi. Universitas Islam Negeri Syarif Hidayatullah, Jakarta

Hakim, N., et al 1986.Dasar-dasar ilmu tanah. Universitas Lampung. Lampung,

Hariyadi, 2008. Budidaya Tanaman Jarak (Jatropha Curcas L) sebagai sumber bahan alternatif biofuel. www.kabprobolinggo.go.id/artikeldanris et. Diakses pada tanggal 03 April 2016.

Hartmann, H.T., Kester DE. 1983. Plant Propagation-Principles and Practices. New Jersey (US). Prentice Hall International Inc. 238p.
Krisnadi, A Dudi., 2015, Kelor Super Nutrisi, http://www. kelorina.com.Diakses pada tanggal 03April 2016

Kusumawardana, A. 2008. Pengaruh Konsentrasi Rootone-F dan Jenis Media Tanam terhadap Pertumbuhan Stek Panili (Vanilla Planifolia Andrews). Departemen Agronomi dan Hortikultura Fakultas Pertanian IPB. Bogor.

Musnawar, E.I. (1992). Pupuk Organik. Penebar Swadaya. Jakarta.

Nugroho, A. W. 2013. Pengaruh Komposisi Media Tanam terhadap Pertumbuhan Awal Cemara Udang (Casuarina equisetifolia var. Incana) Pada Gumuk Pasir Pantai. Forest Rehabilitation Journal, Vol. 1 (1): 113 -125

Prawitasari, T. 2009. Praktek Seleksi Stek untuk bibit Jarak Pagar. Workshop Pendirian Kebun Bibit Sumber. Demplot dan Feasibility Study untuk Perkebunan Jarak Pagar (Jatropha Curcas L) Bogor. Surfactant and Bioenergy Research Center-LPPM-IPB

Purwowidodo, 1983. Teknologi Mulsa. Dewa Ruci. Jakarta.

Sawaludin, Aluh N., dan Bambang B. S., 2018. Pengaruh Berbagai Macam Media Terhadap Pertumbuhan Bibit Kelor (Moringa Oleifera Lam.) Asal Stek Batang. Jurnal Sains Teknologi dan Lingkungan. Vol. 4(01): 31-42 